\title{
Evaluasi Penerapan Standar Pelayanan Minimal Pada Ruas Jalan Provinsi Di Kota Kendari Sulawesi Tenggara
}

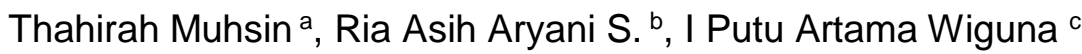

\begin{abstract}
Road Minimum Service Standards (MSS) is a road's technical measure that must be realized by the road administrator so that the roads are able to operate in accordance with the service standards stipulated. The stipulation of road MSS is regulated through Regulation of Minister of Public Works No. 01/Prt/M/2014 on Minimum Service Standards of Public Works and Spatial Planning that have two indicators basic road service are the level of good and medium provincial road conditions as well as the connection between activity centers and production centers (connectivity) in the province. This research aims to discuss about evaluation the condition and connectivity of the road that is implemented in the provincial road segments in Kendari City. The method that used in this research are indentified about the existing condition and connectivity of the road and distribute questionnaires to the road users to knowing about their perception about the service of Province's road in Kendari City with using secondary datas from Dinas Sumber Daya Air dan Bina Marga Provinsi Sulawesi Tenggara dan primary datas from observation on provincial roads in Kendari and questionnaires distribution to road users. Evaluation factors consisting of public services factors that have been implemented on the provincial road segments in Kendari with the Discrepancy Evaluation Method that direct comparison between the data obtained from the observation and interviews with the target achievement stipulated in Ministerial Regulationof Public Works No. 1/PRT/M/2014. The result of this research on 10 (ten) provincial roads in Kendari City shows the level of good and medium provincial road conditions as well about 55,60\% with the standard is $\mathbf{6 0 \%}$, the level of the connectivity in the province about $\mathbf{8 9 , 4 0 \%}$ with standard in the regulation is $\mathbf{1 0 0 \%}$ and according to the perception of road users, level of service road conditions about 49,25\% and level of connectivity of the provincial roads in Kendari City is about $\mathbf{8 1 , 2 \%}$.
\end{abstract}

Keywords: road condition, connectivity, provincial road, minimum service standards, Kendari City

\begin{abstract}
Abstrak: Standar Pelayanan Minimal jalan adalah ukuran teknis jalan yang harus diwujudkan oleh penyelenggara jalan agar jalan dapat beroperasi sesuai dengan standar pelayanan yang ditetapkan. Penetapan standar pelayanan minimal jalan lebih lanjut diatur melalui Peraturan Menteri Pekerjaan Umum No. 01/Prt/M/2014 Tentang Standar Pelayanan Minimal Bidang Pekerjaan Umum Dan Penataan Ruang dengan indikator pelayanan dasar bidang jalan terdiri atas tingkat kondisi jalan provinsi baik dan sedang serta terhubungnya pusat-pusat kegiatan dan pusat produksi (konektivitas) di wilayah provinsi. Penelitian ini dimaksudkan untuk mengevaluasi kondisi serta konektivitas jalan provinsi di Kota Kendari dalam upaya penerapan standar pelayanan minimalbidang jalan. Metode yang dilakukan dalam penelitian ini adalah dengan mengidentifikasi kondisi eksisting dan konektivitas jalan serta persepsi masyarakat mengenai pelayanan jalan provinsi di Kota Kendari. Evaluasi dilakukan dengan Model Evaluasi Ketimpangan (The Discrepancy Evaluation Method) yaitu melakukan perbandingan langsung antara data yang diperoleh dari hasil observasi dan penyebaran kuesioner dengan target capaian yang telah ditetapkan. Dari hasil penelitian terhadap 10 (sepuluh) ruas jalan provinsi di Kota Kendarimenunjukkan bahwa kondisi jalan provinsi dalam keadaan baik dan sedang (mantap) sebesar 55,60\% dimana standar pelayanan minimalnya adalah 60\% sedangkan nilai konektivitas jalan adalah sebesar 89,40\% dengan standar pelayanan minimal $100 \%$ dan menurut persepsi pengguna jalan, tingkat pelayanan kondisi jalan adalah sebesar 49,25\% dan tingkat konektivitas di Kota Kendari sebesar $81,2 \%$.
\end{abstract}

Kata Kunci : kondisi jalan, konektivitas, jalan provinsi, standar pelayanan minimal, Kota Kendari

\section{PENDAHULUAN}

Jalan merupakan infrastruktur yang dibangun oleh pemerintah untuk memperlancar pengembangan daerah sehingga menjadi aset yang harus dikelola dan difungsikan secara optimal. Namun pada kenyataannya, kinerja ruas jalan yang berstatus jalan provinsi maupun jalan kota/kabupaten seringkali belum memenuhi Standar Pelayanan Minimal (SPM) yang telah ditetapkan.

Untuk menjamin ketersediaan jalan yang memenuhi SPM, maka diterbitkan Peraturan Menteri Pekerjaan

aPersonnel at Dinas Perumahan Rakyat, Kawasan Permukiman, dan Pertahanan, and a student in the Department of Civil Engineering, Sepuluh Nopember Institute of Technology (ITS), ITS Campus, Sukolilo, Surabaya 60111, Indonesia. Email: ira.muhsin@gmail.com

b,c Lecturer in the Department of Civil Engineering, Sepuluh Nopember Institute of Technology (ITS), ITS Campus, Sukolilo, Surabaya 60111, Indonesia. Email: ria@ce.its.ac.id, artama@ce.its.ac.id

Note. The manuscript for this paper was submitted for review and possible publication on January 08, 2018. This paper is part of the ITS Journal of Civil Engineering, Vol. 33, No. 1, May 2018. (C) ITS Journal of Civil Engineering, ISSN 2579-9029/2017.
Umum Nomor 1/PRT/M/2014 tentang Standar Pelayanan Minimal Bidang Pekerjaan Umum dan Penataan Ruangyang salah satu jenis pelayanannya adalah penyediaan jalan untuk melayani kebutuhan masyarakat dengan indikator penyediaan jalan dalam kondisi baik dan sedang serta terhubungnya pusat kegiatan dan pusat produksi dalam wilayah provinsi [1].

Namun pada kenyataannya, kinerja ruas jalan yang berstatus jalan provinsi maupun jalan kota/kabupaten seringkali belum memenuhi SPM yang telah ditetapkan. Untuk itu, penelitian ini bermaksud mengevaluasi penerapan SPM jalan yang meliputi dasar hukum, kondisi jalan serta konektivitas untuk memberikan pelayanan jalan yang optimal kepada pengguna ruas jalan provinsi di Kota kendari.

Cara menyatakan keberhasilan penyelenggaraan jalan berubah dari pola pencapaian menggunakan model kemantapan jalan menjadi pencapaian SPM Jalan [2]. SPM bidang jalan terdiri atas 2 indikator capaian SPM penyediaan jalan untuk melayani kebutuhan masyarakat yaitu kondisi jalan baik dan sedang serta terhubungnya 
pusat-pusat kegiatan dan pusat produksi (konektivitas) di wilayah provinsi [1].

\section{- SPM Kondisi Jalan}

Persentase target capaian SPM penyediaan jalan untuk melayani kebutuhan masyarakat melalui peningkatan kualitas layanan jalan (provinsi/ kabupaten/ kota) adalah tingkat kondisi jalan (baik dan sedang) $60 \%$ pada tahun 2019. Adapun cara untuk menghitung SPM Kondisi Jalan adalah dengan menggunakan rumus sebagai berikut [1]:

SPM Kondisi Jalan $=\frac{\sum \text { Panjang jalan memenuhi Kondisi Jalan Baik dan Sedang }}{\sum P a n j a n g ~ J a l a n P r o v i n s i}$ $\sum$ Panjang Jalan Provinsi

Tingkat kondisi jalan dinilai berdasarkan nilai International Roughness Index (IRI) yang dapat diperoleh menggunakan alat (Naasra/ Romdas/ Roughometer) atau metode visual (Road Condition Index/ RCI). Berdasarkan tingkat IRI, kondisi jalan terbagi atas [3]:

- Untuk jalan aspal (paved): baik (IRI $\leq 4)$; sedang (IRI $>4$ dan $\mathrm{IRI} \leq 8)$; rusak ringan $(\mathrm{IRI}>8$ dan $\mathrm{IRI} \leq 12)$; dan rusak berat (IRI $>12)$.

- Untuk jalan penmac (paved): baik (IRI $\leq 8$ ); sedang $($ IRI $>8$ dan $\mathrm{IRI} \leq 10)$; rusak ringan $($ IRI $>10$ dan IRI $\leq 12)$; dan rusak berat (IRI $>12$ )

- Untuk jalan tanah/kerikil (unpaved): baik (IRI $\leq 10$ ); sedang $($ IRI $>10$ dan IRI $\leq 12)$; rusak ringan $($ IRI $>$ 12 dan $\mathrm{IRI} \leq 16)$; dan rusak berat ( IRI $>16)$.

Dengan menggunakan metode visual RCI dalam Tabel 1, kondisi jalan dapat ditentukan dengan survey kondisi permukaan perkerasan yang diinterpetasikan dengan nilai RCI [3]. Nilai RCI tersebut kemudian dikonversikan ke nilai IRI dengan menggunakan hubungan antara RCI dan nilai IRI dengan persamaan 2. Sebagai berikut:

$$
I R I=\frac{\ln \left(\frac{R C I}{10}\right)}{-0,094}
$$

\section{Keterangan: \\ IRI : International Roughness Index \\ RCI : Road Condition Index \\ EXP (1) : bilangan e $=2,718281828182$}

\section{- SPM Konektivitas}

Persentase target capaian SPM penyediaan jalan untuk melayani kebutuhan masyarakat melalui penyediaan konektivitas wilayah provinsi/kabupaten/ kota adalah $100 \%$ pada tahun 2019. Cara perhitungan SPM Konektivitas Wilayah adalah dengan menggunakan rumus sebagai berikut:

$S P M$ Konektivitas $=\frac{\sum \text { Panjang Jalan penghubung pusat kegiatan dan pusat produksi }}{\sum \text { Panjang jalan penghubungpusat kegiatan dan pusat produksi }}(3)$
Untuk menghitung tingkat pelayanan menurut persepsi masyarakat adalah dengan menggunakan Relative Importance Index(RII) [4]. Perhitungan RII dilakukan untuk setiap indikator dengan nilai RII yang diperoleh berada pada rentang nilai 0 sampai dengan 1 dengan rumus:

$R I I=\frac{\sum_{i=1}^{4} W i X i}{A x N}$

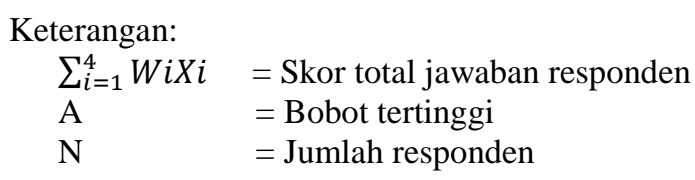

\section{KEPENTINGAN RISET}

Pelaksanaan kegiatan penanganan jalan di ruas-ruas jalan provinsi di Kota Kendari telah dilaksanakan tiap tahun, namun karena kurangnya perhatian dari penyelenggara jalan provinsi tentang Standar Pelayanan Minimal, kegiatan tersebut belum optimal mempertimbangkan manfaat jalan bagi masyarakat terutama pengguna jalan itu sendiri.

Hal lain yang mendasari penelitian ini adalah karena Standar Pelayanan Minimal bidang jalan hanya terbatas pada dua indikator kondisi jalan dan konektivitasnya, maka menjadi penting untuk dikaji lebih jauh mengenai hubungan antara kondisi jalan yang ada dengan tingkat konektivitas yang diberikan oleh suatu ruas jalan [5].

Adapun tujuan dari penelitian ini adalah:

1. Mengetahui kondisi eksisting penerapan Standar Pelayanan Minimal Bidang Jalan pada ruas jalan provinsi di Kota Kendari.

2. Mengevaluasi penerapan Standar Pelayanan Minimal Bidang Jalan pada ruas jalan provinsi di Kota Kendari.

3. Mengidentifikasi kendala penerapan Standar Pelayanan Minimal Bidang Jalan pada ruas jalan provinsi di Kota Kendari.

\section{METODOLOGI}

Penelitian ini termasuk penelitian evaluasi pelaksanaan SPM dengan metode evaluasi ketimpangan atau kesenjangan (The Discrepancy Evaluation Model) [6], dimana penelitian ini akan membandingkan secara langsung pelaksanaan SPM dengan indikator menurut Permen PU 1/14serta membandingkan kondisi eksisting kondisi jalan yang ada dilapangan dengan persepsi dari pengguna jalan. 
Tabel 1. Korelasi antara Nilai RCI dan Jenis Permukaan Jalan

\begin{tabular}{cllc}
\hline No & \multicolumn{1}{c}{ Jenis Permukaan } & \multicolumn{1}{c}{ Kondisi yang Ditinjau secara Visual } & Nilai RCI \\
\hline 1. Jalan tanah dengan drainase yang jelek, dan \\
$\begin{array}{l}\text { semua tipe permukaan yang tidak } \\
\text { diperhatikan sama sekali }\end{array}$
\end{tabular}

Tabel 2. Jumlah Populasi dan Sampel Pengguna Jalan

\begin{tabular}{clcc}
\hline No & \multicolumn{1}{c}{ Ruas Jalan } & LHR & $\begin{array}{c}\text { Jumlah } \\
\text { Sampel }\end{array}$ \\
\cline { 3 - 4 } & & & Smp \\
\hline 1. & Jl. Lingkar Kota & 150 & 10 \\
2. & Jl. H. Lamuse & 400 & 23 \\
3. & Jl. Orinunggu & 400 & 23 \\
4. & Jl. Pangeran Antasari & 400 & 23 \\
5. & Jl. Dewi Sartika & 400 & 23 \\
6. & J1. Brigjen Katamso & 500 & 23 \\
7. & Jl. Sudirman & 500 & 23 \\
8. & Jl. RA. Kartini & 500 & 23 \\
9. & Jl. Martadinata & 500 & 23 \\
10. & Batas Kota - Dr. Sutomo & 500 & 23 \\
\hline & $\quad$ Jumlah & 4250 & 217 \\
\hline
\end{tabular}

\section{- Kebutuhan Data}

Data sekunder yang dikumpulkan dari Dinas Sumber Daya Air dan Bina Marga Provinsi. Sulawesi Tenggara (SDA dan BM Prov. Sultra) yaitu data peta jaringan jalan, kondisi jalan, data Lalu Lintas Harian Rata-rata (LHR) data pusat produksi dan pusat kegiatan serta Rencana Tata Ruang Wilayah (RTRW) Provinsi Sulawesi Tenggara dan Kota Kendari.

Sedangkan untuk pengumpulan data primer dilakukan dengan melakukan survei kondisi jalan, survei konektivitas jalan, penyebaran kuesioner kepada pengguna jalan serta wawancara kepada tenaga ahli dari Bidang Bina Marga Dinas SDA dan BM Prov. Sultra.

\section{- Populasi dan sampel Penelitian}

Dalam penelitian ini, digunakan dua populasi yang akan dijadikan sebagai objek penelitian yaitu:

1. Pengguna Jalan

Penarikan sampel dari populasi pengguna jalan menggunakan metode Non-Probability Sampling dengan teknik quota convenient sampling[7] . Tabel 2 menunjukkan jumlah populasi dan sampel penelitian.

Tabel 3. Sampel untuk Wawancara

\begin{tabular}{clcc}
\hline \multirow{2}{*}{ No. } & Bidang Bina Marga & Jabatan & Jumlah \\
\cline { 3 - 4 } 1. & Perencanaan & Kepala & Orang \\
2. & $\begin{array}{l}\text { Pembangunan Jalan dan } \\
\text { Kepala }\end{array}$ & 1 \\
3. & $\begin{array}{l}\text { Jembatan } \\
\text { Preservasi Jalan dan }\end{array}$ & $\begin{array}{c}\text { Seksi } \\
\text { Kepala } \\
\text { Seksi }\end{array}$ & 1 \\
4. & Staf & Staf Teknis & 2 \\
\hline \multicolumn{2}{r}{} \\
\hline
\end{tabular}

2. Penyelenggara Jalan

Penarikan sampel dari penyelenggara jalan yaitu dengan metode pengambilan sampel Probability Sampling dengan teknik Stratified Sampling yang dapat dilihat pada Tabel 3 [7].

Data yang dikumpulkan kemudian diolah dan dianalisis untuk dapat menjawab tujuan dari penelitian ini. Teknik analisis data dalam penelitian ini dilakukan dengan cara, yaitu:

a. Analisa Kondisi Eksisting Standar Pelayanan Minimal Jalan Provinsi di Kota Kendari

Untuk melakukan analisa kondisi eksisting Standar Pelayanan Minimal pada ruas jalan provinsi di Kota Kendari digunakan rumus (1) dan rumus (3).

Setelah nilai untuk Standar Pelayanan Minimal kondisi jalan dan konektivitas jalan diperoleh, kemudian dilakukan analisa lanjutan yang dapat menghitung indeks hubungan antara kondisi jalan dengan konektivitas dengan rumus: 
Tabel 4. Kategori Nilai Indeks Links

\begin{tabular}{|c|l|}
\hline $\begin{array}{c}\text { Nilai } \\
\text { Indeks } \\
\text { Links }\end{array}$ & \multicolumn{1}{c|}{ Penjelasan } \\
\hline$<0,2$ & $\begin{array}{l}\text { Konektivitas sangat buruk. } \\
\text { Kendaraan hamper tidak bisa mengalir } \\
\text { dengan gangguan hampir sepanjang } \\
\text { jalan }\end{array}$ \\
\hline $0,2-0,4$ & $\begin{array}{l}\text { Konektivitas buruk. Aliran } \\
\text { kendaraan merayap lambat dan } \\
\text { tersendat-sendat dengan banyak } \\
\text { gangguan }\end{array}$ \\
\hline $0,4-0,6$ & $\begin{array}{l}\text { Konektivitas sedang. Aliran } \\
\text { kendaraan merayap tanpa sendatan } \\
\text { dengan banyak gangguan }\end{array}$ \\
\hline $0,6-0,8$ & $\begin{array}{l}\text { Konektivitas baik. Aliran kendaraan } \\
\text { lancar namun masih dijumpai sedikit } \\
\text { gangguan }\end{array}$ \\
\hline$>0,8$ & $\begin{array}{l}\text { Konektivitas sangat baik. Aliran } \\
\text { kendaraan lancar hampir tanpa } \\
\text { gangguan }\end{array}$ \\
\hline Sumber : Balitbang PUPR, 2016
\end{tabular}

Indeks Links $=\left\{\left(\frac{\frac{1}{\text { IndeksIRI }+ \text { Indeks Kecepatan }}}{2}\right)\right\}$

Indeks IRI $=\left[\frac{1-\left(\frac{\text { Nilai IRI }}{12}\right)}{1-\frac{4}{12}}\right]$

Indeks kecepatan $=\frac{\text { Nilai Kecepatan }}{40}$

Dengan kategori nilai indeks links sebagai berikut:

b. Evaluasi Penerapan Standar Pelayanan Minimal

Untuk mengetahui tingkat layanan jalan provinsi yang telah diterima oleh pengguna jalan dilakukan analisis dengan menggunakan metode Relative Importance Index (RII) dengan menggunakan rumus (4) dari masing-masing indikator kuesioner yang telah diuji validitasnya. Nilai RII setiap indikator berada antara nilai 0 dan $1(0 \leq$ RII $\leq 1)$.

Setelah semua data responden dihitung dengan menggunakan RII, maka dari nilai persentasi kondisi eksisting dan persentasi persepsi pengguna jalan tersebut kemudian dianalisa dengan Uji Beda Berpasangan (Paired Sample T Test) dengan bantuan SPSS Statistic 20 yang dapat menunjukkan apakah terdapat perbedaan yang signifikan antara kondisi jalan eksisting dengan persepsi pengguna jalan.

Untuk melakukan interpretasi terhadap uji beda berpasangan terlebih dahulu ditentukan nilai signifikansi $\alpha$ dan df (degree of freedom) yang mana untuk uji beda berpasangan nilai df ditentukan sebesar N-1. Dengan hipotesis sebagai berikut:

$$
\begin{aligned}
& H_{0}: \mu_{1}=\mu_{2} \\
& H_{1}: \mu_{1} \neq \mu_{2}
\end{aligned}
$$

Dengan penentuan daerah kritis yaitu:

- Jika $\mathrm{T}_{\text {hitung }} \geq \mathrm{T}_{\text {Tabel }}$ : Tolak $\mathrm{H}_{0}$

- $\mathrm{T}_{\text {hitung }} \leq \mathrm{T}_{\text {Tabel }}$ : Tolak $\mathrm{H}_{0}$

- Jika Sig. $\leq \alpha$ : Tolak $\mathrm{H}_{0}$
Tabel 5. Ruas Jalan Provinsi di Kota Kendari

\begin{tabular}{clcc}
\hline \multirow{2}{*}{ No } & \multicolumn{1}{|}{ Nama Ruas Jalan } & $\begin{array}{c}\text { Panjang } \\
\text { Ruas }\end{array}$ & $\begin{array}{c}\text { Lebar } \\
\text { Rerata } \\
\text { Ruas }\end{array}$ \\
\cline { 3 - 4 } & & $K m$ & $m$ \\
\hline $\mathbf{1}$ & Jln. Lingkar Kota Kendari & 38,15 & 40,00 \\
$\mathbf{2}$ & Jln. H. Lamuse (Kendari) & 1,60 & 4,50 \\
$\mathbf{3}$ & Jln. Orinunggu (Kendari) & 3,15 & 4,50 \\
$\mathbf{4}$ & Jln. Pangeran Antasari & 2,55 & 4,50 \\
& (Kendari) & 4,50 & 4,50 \\
$\mathbf{5}$ & Jln. Dewi Sartika (Kendari) & 2,69 & 12,00 \\
$\mathbf{6}$ & Jln. Brigjen Katamso & & \\
& (Kendari) & 0,91 & 4,50 \\
$\mathbf{7}$ & Jln. Sudirman (Kendari) & 1,50 & 4,50 \\
$\mathbf{8}$ & Jln. Ra. Kartini (Kendari) & 4,10 & 4,50 \\
$\mathbf{9}$ & Jln. Martadinata (Kendari) & 7,07 & 4,50 \\
$\mathbf{1 0}$ & Bts Kota Kendari (Labibia) & & \\
\hline \multicolumn{3}{c}{ Panjang Total } \\
\hline Sumber: Dinas SDA dan BM Prov. Sultra, 2017 &
\end{tabular}

c. Analisis Kendala Penerapan Standar Pelayanan Minimal

Setelah dilakukan evaluasi terhadap penerapan Standar Pelayanan Minimal pada ruas jalan provinsi di Kota Kendari, kemudian dilakukan analisis terhadap hasil wawancara yang dilakukan kepada tenaga ahli (expert) dari Bidang Bina Marga Dinas Sumber Daya Air dan Bina Marga Provinsi Sulawesi Tenggara dengan analisis deskriptif.

\section{ANALISIS DAN PEMBAHASAN}

Jenis pelayanan penyediaan jalan untuk melayani kebutuhan masyarakat dibagi dalam dua indikator yang dicapai secara bertahap dengan batas waktu capaian dari tahun 2014 hingga tahun 2019 yaitu:

1) Persentase tingkat kondisi jalan provinsi baik dan sedang sebesar $60 \%$

2) Persentase terhubungnya pusat-pusat kegiatan dan pusat produksi (konektivitas) di wilayah provinsi sebesar $100 \%$. [1]

\section{- Lokasi Penelitian}

Penelitian ini akan dilaksanakan pada ruas - ruas jalan provinsi yang berada di Kota Kendari. Gambar 1 adalah peta jaringan jalan yang menjadi lokasi penelitian.

Pada tahun 2017 terdapat 10 (sepuluh) ruas jalan jalan Provinsi yang ada di Kota Kendari yang dapat dilihat pada Tabel 5 berikut.

\section{- Kondisi Jalan Provinsi di Kota Kendari}

Panjang jaringan jalan provinsi di kota Kendari pada tahun 2017 tercatat sepanjang 66,22 Km.

Tipe perkerasan dan kondisi perkerasan jalan provinsi yang ada di Kota Kendari tersebut dapat dilihat pada Gambar 2 berikut.

\section{- Pusat Produksi dan Pusat Kegiatan di Kota Kendari}

Berdasarkan RTRW Kota Kendari terdapat 12 pusat pelayanan kegiatan yang ada di Kota Kendari dapat dilihat pada Tabel 6 berikut: [8] 


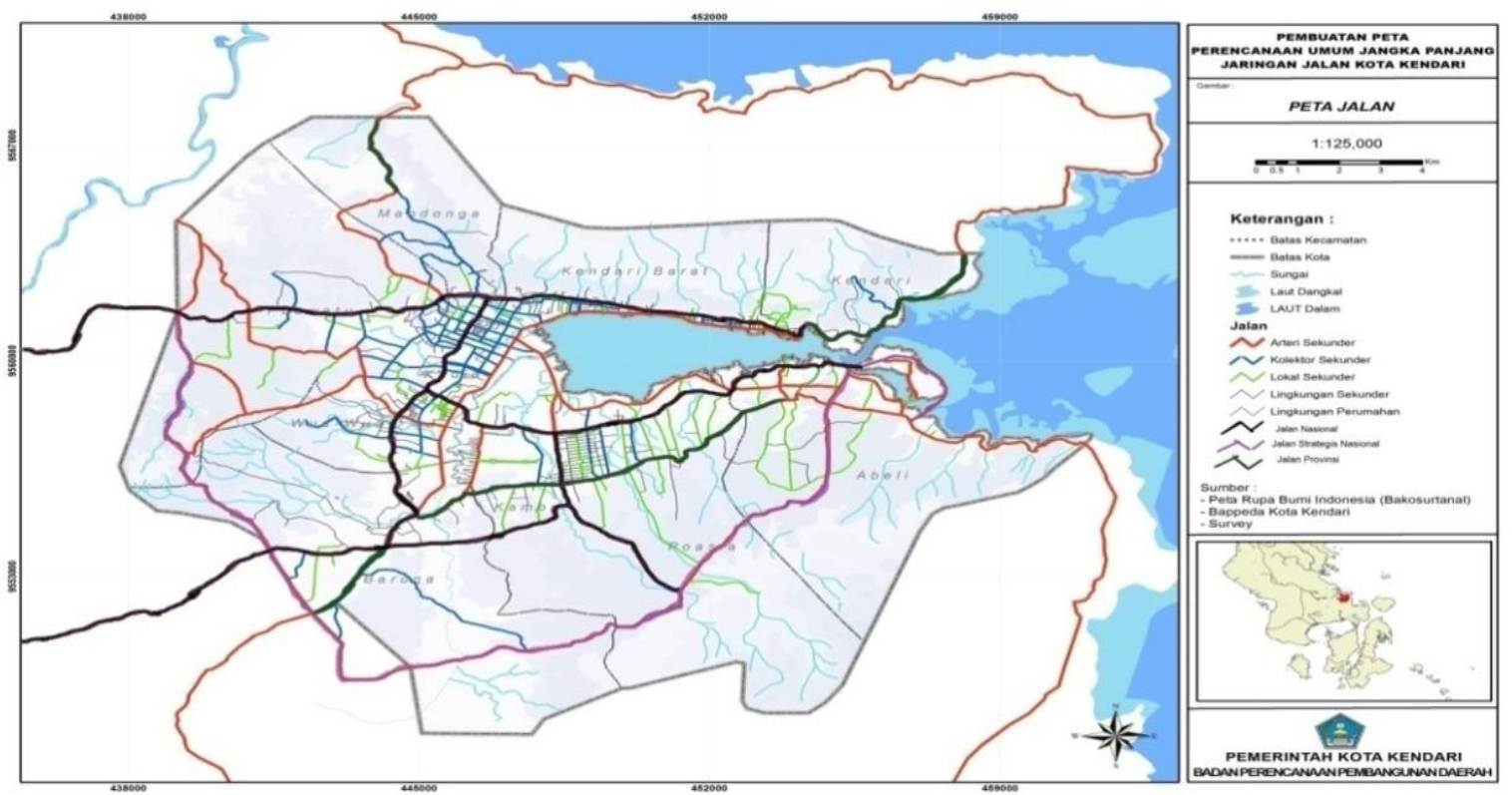

Gambar 1. Peta Jaringan Jalan Provinsi Di Kota Kendari
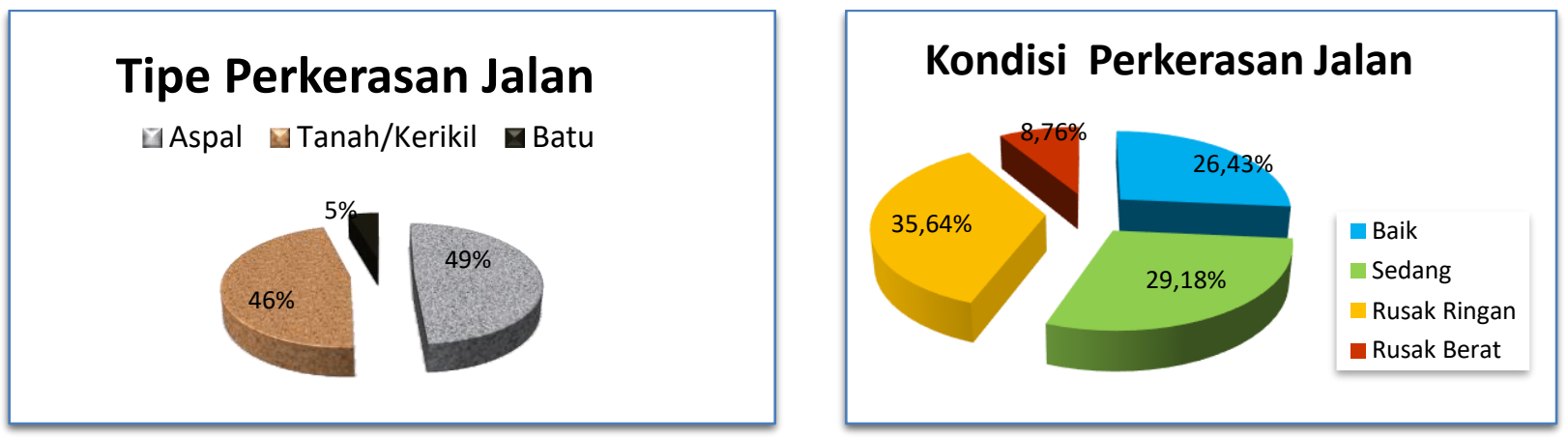

Gambar 2. Kondisi Jalan Provinsi di Kota Kendari Tahun 2017

Tabel 6. Pusat Kegiatan di Kota Kendari

\begin{tabular}{llc}
\hline No & \multicolumn{1}{c}{ Pusat Kegiatan } & Kategori \\
\hline 1. & Kawasan pusat pemerintahan Kota Kendari & PKW \\
2. & Kawasan strategis Teluk Kendari & PKW \\
3. & Pusat kegiatan kesehatan RS. Umum Abu Nawas & PKL \\
4. & Pusat kegiatan kesehatan RS. Umum Bahteramas & PKN \\
5. Kawasan pelabuhan perikanan samudera & PKW \\
6. Kawasan Pelabuhan Nusantara & PKW \\
7. Kawasan terminal regional tipe A & PKW \\
8. Kawasan pendidikan tinggi (UHO) & PKN \\
9. Kawasan pusat perkantoran Pemerintah Provinsi Sulawesi Tenggara (Kantor & \\
10. J. Kawasan pusat bisnis dan perdagangan Kota Lama & PKL \\
11. 1. Pasar tradisional & PKL \\
12. 2. Kawasan pusat perbelanjaan & PKL \\
\hline
\end{tabular}

\section{- Kondisi Eksisting}

Analisa kondisi eksisting dilakukan Berdasarkan penelitian yang telah dilaksanakan pada ruas jalan provinsi di Kota Kendari, dapat diketahui tingkat pelayanan jalan yang dicapai pada tahun 2017 yaitu:

\section{Kondisi Jalan}

Kondisi jalan provinsi yang ada di Kota Kendari di semester pertama tahun 2017 dapat dilihat pada Tabel 7. Dari tabel tersebut, diketahui: 
Tabel 7. Kondisi Ruas Jalan Provinsi di Kota Kendari

\begin{tabular}{|c|c|c|c|c|c|c|c|c|c|c|c|}
\hline \multirow{3}{*}{ No. } & \multirow{3}{*}{ Nama Ruas Jalan } & \multirow{3}{*}{$\begin{array}{c}\begin{array}{c}\text { Panjang } \\
\text { Ruas }\end{array} \\
\mathrm{Km}\end{array}$} & \multirow{3}{*}{$\begin{array}{c}\begin{array}{c}\text { Lebar } \\
\text { Ruas }\end{array} \\
m\end{array}$} & \multicolumn{8}{|c|}{ Panjang Tiap Kondisi (KM) } \\
\hline & & & & \multicolumn{2}{|c|}{ Baik } & \multicolumn{2}{|c|}{ Sedang } & \multicolumn{2}{|c|}{ Rusak Ringan } & \multicolumn{2}{|c|}{ Rusak Berat } \\
\hline & & & & $K m$ & $\%$ & $\mathrm{Km}$ & $\%$ & $K m$ & $\%$ & $K m$ & $\%$ \\
\hline 1 & $\begin{array}{l}\text { Jln. Lingkar Kota } \\
\text { Kendari }\end{array}$ & 38.15 & 40.00 & 2.00 & 5.24 & 12.15 & 31.85 & 19.00 & 49.80 & 5.00 & 13.11 \\
\hline 2 & Jln. H. Lamuse & 1.60 & 4.50 & 0.00 & 0.00 & 0.80 & 50.00 & 0.60 & 37.50 & 0.20 & 12.50 \\
\hline 3 & Jln. Orinunggu & 3.15 & 4.50 & 2.45 & 77.78 & 0.70 & 22.22 & 0.00 & 0.00 & 0.00 & 0.00 \\
\hline 4 & $\begin{array}{l}\text { Jln. Pangeran } \\
\text { Antasari }\end{array}$ & 2.55 & 4.50 & 2.55 & 100.0 & 0.00 & 0.00 & 0.00 & 0.00 & 0.00 & 0.00 \\
\hline 5 & Jln. Dewi Sartika & 4.50 & 4.50 & 0.50 & 11.11 & 2.00 & 44.44 & 1.90 & 42.22 & 0.10 & 2.22 \\
\hline 6 & Jln. Brigjen Katamso & 2.69 & 12.00 & 2.59 & 96.28 & 0.10 & 3.72 & 0.00 & 0.00 & 0.00 & 0.00 \\
\hline 7 & Jln. Sudirman & 0.91 & 4.50 & 0.71 & 78.02 & 0.10 & 10.99 & 0.10 & 10.99 & 0.00 & 0.00 \\
\hline 8 & Jln. Ra. Kartini & 1.50 & 4.50 & 1.10 & 73.33 & 0.40 & 26.67 & 0.00 & 0.00 & 0.00 & 0.00 \\
\hline 9 & Jln. Martadinata & 4.10 & 4.50 & 3.60 & 87.80 & 0.40 & 9.76 & 0.10 & 2.44 & 0.00 & 0.00 \\
\hline 10 & $\begin{array}{l}\text { Bts Kota Kendari } \\
\text { (Labibia) - Dr. } \\
\text { Sutomo }\end{array}$ & 7.07 & 4.50 & 2.00 & 28.29 & 2.67 & 37.77 & 1.90 & 26.87 & 0.50 & 7.07 \\
\hline \multicolumn{2}{|c|}{ Panjang Jalan $(\mathrm{Km})$} & 66.22 & & $\mathbf{1 7 . 5 0}$ & & 19.32 & & 23.60 & & 5.80 & \\
\hline \multicolumn{2}{|c|}{ Persentase Kondisi jalan (\%) } & & & & 26.43 & & 29.18 & & 35.64 & & 8.76 \\
\hline
\end{tabular}

Sumber: Dinas SDA dan BM Pro. Sultra, 2017

- Panjang jalan (eksisting) Kota Kendari $=66,22 \mathrm{Km}$

- Rencana panjang jalan kondisi baik dan sedang $=60 \% \times 66,22$

- Realisasi panjang jalan kondisi baik dan sedang

Sehingga:
SPMKondisiJalan $=\frac{36,82 \mathrm{Km}}{66,22 \mathrm{Km}} \times 100 \%=\mathbf{5 5 , 6 0 \%}$

Tingkat capaian Standar Pelayanan Minimal masingmasing ruas jalan Kota Kendari dapat dilihat pada Tabel 8.

Tabel 8. Tingkat Rata-Rata Kondisi Jalan Provinsi di Kota Kendari

\begin{tabular}{|c|c|c|c|c|c|c|c|}
\hline \multirow[t]{2}{*}{ No. } & \multirow[t]{2}{*}{ Nama Ruas } & \multirow[t]{2}{*}{ SDI } & \multirow[t]{2}{*}{ RCI } & \multirow[t]{2}{*}{ IRI } & \multirow[t]{2}{*}{ Kriteria } & $\begin{array}{l}\text { Kondisi } \\
\text { Mantap }\end{array}$ & \multirow[t]{2}{*}{ Capaian Target SPM } \\
\hline & & & & & & $\%$ & \\
\hline 1 & J1. Lingkar Kota Kendari & 42.93 & 7.07 & 4.50 & Baik & 37.09 & Belum Memenuhi \\
\hline 2 & J1. H. La Muse & 37.50 & 6.00 & 5.58 & Baik & 50.00 & Belum Memenuhi \\
\hline 3 & $\mathrm{Jl}$. Orinunggu & 18.87 & 7.13 & 3.78 & Baik & 100.00 & Memenuhi \\
\hline 4 & Jl. Pangeran Antasari & 3.85 & 7.50 & 3.08 & Baik & 100.00 & Memenuhi \\
\hline 5 & Jl. Dewi Sartika & 18.94 & 6.98 & 3.91 & Baik & 55.55 & Belum Memenuhi \\
\hline 6 & Jl. Brigjen Katamso & 4.07 & 7.74 & 2.75 & Baik & 100.00 & Memenuhi \\
\hline 7 & Jl. Sudirman & 22.22 & 6.33 & 5.04 & Baik & 89.01 & Memenuhi \\
\hline 8 & Jl. RA Kartini & 28.00 & 6.67 & 4.46 & Baik & 100.00 & Memenuhi \\
\hline 9 & Jl. Martadinata & 14.02 & 7.27 & 3.53 & Baik & 97.56 & Memenuhi \\
\hline 10 & Batas Kota - Dr. Sutomo & 12.02 & 7.21 & 3.55 & Baik & 66.06 & Memenuhi \\
\hline
\end{tabular}

Tabel 9. Kebutuhan Panja ng Jalan Provinsi di Kota

\begin{tabular}{|c|c|c|c|}
\hline \multicolumn{4}{|c|}{ Kendari } \\
\hline \multirow[t]{2}{*}{ No } & \multirow[t]{2}{*}{ Nama Ruas } & $\begin{array}{c}\text { Panjang } \\
\text { Jalan }\end{array}$ & $\begin{array}{c}\text { Kebutuhan } \\
\text { Panjang } \\
\text { Jalan }\end{array}$ \\
\hline & & $K m$ & Km \\
\hline 1 & $\begin{array}{l}\text { Jln. Lingkar Kota } \\
\text { Kendari }\end{array}$ & 38.15 & 46.00 \\
\hline 2 & Jln. H. Lamuse & 1.60 & 1.60 \\
\hline 3 & Jln. Orinunggu & 3.15 & 3.15 \\
\hline 4 & $\begin{array}{l}\text { Jln. Pangeran } \\
\text { Antasari }\end{array}$ & 2.55 & 2.55 \\
\hline 5 & Jln. Dewi Sartika & 4.50 & 4.50 \\
\hline 6 & Jln. Brigjen Katamso & 2.69 & 2.69 \\
\hline 7 & Jln. Sudirman & 0.91 & 0.91 \\
\hline 8 & Jln. Ra. Kartini & 1.50 & 1.50 \\
\hline 9 & Jln. Martadinata & 4.10 & 4.10 \\
\hline \multirow[t]{4}{*}{10} & Bts Kota Kendari & 7.07 & 7.07 \\
\hline & (Labibia) - Dr. & & \\
\hline & Sutomo & & \\
\hline & Jumlah & 66.22 & 74.07 \\
\hline
\end{tabular}

Tabel 11. Uji Perbandingan dengan Persepsi Pengguna Jalan

\begin{tabular}{|c|c|c|c|}
\hline \multirow[t]{2}{*}{ No. } & \multirow[t]{2}{*}{ Nama Ruas } & $\begin{array}{l}\text { Kondisi } \\
\text { Eksisting }\end{array}$ & $\begin{array}{c}\text { Persepsi } \\
\text { Pengguna } \\
\text { Jalan }\end{array}$ \\
\hline & & $\%$ & $\%$ \\
\hline 1. & Jl. Lingkar & 44.52 & 70.3 \\
\hline 2. & Jl. H. La Muse & 60 & 43.9 \\
\hline 3. & Jl. Orinunggu & 71.29 & 58.8 \\
\hline 4. & Jl. Pangeran Antasari & 75 & 45.6 \\
\hline 5. & J1. Dewi Sartika & 69.77 & 43.2 \\
\hline 6. & Jl. Brigjen Katamso & 77.41 & 58.8 \\
\hline 7. & Jl. Sudirman & 63 & 40.3 \\
\hline 8. & Jl. RA. Kartini & 67 & 44 \\
\hline 9. & Jl. Martadinata & 72.68 & 40.9 \\
\hline 10. & $\begin{array}{l}\text { Batas Kota (Labibia) - Dr. } \\
\text { Sutomo }\end{array}$ & 72.1 & 46.7 \\
\hline & Total Jumlah & 672.77 & 492.5 \\
\hline
\end{tabular}

Sumber: RTRW Prov. Sultra, 2017 


\section{Konektivitas}

Kebutuhan jaringan jalan provinsi di Kota Kendari yang menghubungkan pusat kegiatan dan pusat produksi sebagaimana dalam Tabel 9. [9]

Persentase target capaian standar pelayanan minimal penyediaan jalan untuk melayani kebutuhan masyarakat melalui penyediaan konektivitas wilayah di Kota Kendari Sulawesi Tenggara dapat dihitung sebagai berikut:
SPM Konektivitas $=\frac{66,22 \mathrm{Km}}{74,07 \mathrm{Km}} \times 100 \%=\mathbf{8 9}, \mathbf{4 0} \%$

Dari hasil analisa data untuk mengetahui hubungan kondisi jalan dengan konektivitas dengan nilai kondisi IRI dan Kecepatan untuk masing-masing ruas jalan provinsi yang ada di Kota Kendari maka dapat dilihat pada Tabel 10 .

Tabel 10. Nilai Indeks Links Jalan Provinsi di Kota Kendari

\begin{tabular}{|c|c|c|c|c|c|c|}
\hline Nama Ruas & Nilai IRI & $\begin{array}{l}\text { Kecepatan } \\
\text { Rata-Rata }\end{array}$ & Indeks IRI & $\begin{array}{c}\text { Indeks } \\
\text { Kecepatan }\end{array}$ & $\begin{array}{c}\text { Indeks } \\
\text { Links }\end{array}$ & Kategori \\
\hline Jl. Lingkar Kota & 4.5 & 55 & 0.938 & 1.375 & 1.22 & Konektivitas Sangat Baik \\
\hline Jl. H. Lamuse & 5.58 & 30 & 0.803 & 0.75 & 0.99 & Konektivitas Sangat Baik \\
\hline Jl. Orinunggu & 3.78 & 40 & 1.028 & 1 & 0.98 & Konektivitas Sangat Baik \\
\hline Jl. Pangeran Antasari & 3.08 & 40 & 1.115 & 1 & 0.95 & Konektivitas Sangat Baik \\
\hline Jl. Dewi Sartika & 3.91 & 35 & 1.011 & 0.875 & 0.93 & Konektivitas Sangat Baik \\
\hline Jl. Brigjen Katamso & 2.75 & 40 & 1.156 & 1 & 0.93 & Konektivitas Sangat Baik \\
\hline Jl. Sudirman & 5 & 35 & 0.875 & 0.875 & 1.01 & Konektivitas Sangat Baik \\
\hline Jl. RA. Kartini & 4.46 & 35 & 0.943 & 0.875 & 0.97 & Konektivitas Sangat Baik \\
\hline Jl. Martadinata & 3.5 & 35 & 1.063 & 0.875 & 0.91 & Konektivitas Sangat Baik \\
\hline Batas Kota-Dr. Sutomo & 3.55 & 40 & 1.056 & 1 & 0.97 & Konektivitas Sangat Baik \\
\hline
\end{tabular}

\section{- Hasil Evaluasi}

Dari hasil perhitungan tingkat capaian kondisi jalan dan konektivitas jalan di atas, kemudian dievaluasi terhadap standar yang telah ditetapkan serta persepsi pengguna jalan.

\section{Kondisi Jalan}

a. Evaluasi terhadap Permen PU Nomor. 1/PRT/M/2014

Tingkat kondisi masing-masing ruas jalan yang dihitung berdasarkan survey manual kondisi jalan per 100 meter dapat dilihat pada Tabel 8 . b. Evaluasi Terhadap Pengguna Jalan

Tingkat pelayanan berdasarkan konsidi jalan dengan survey yang dilakukan terhadap pengguna jalan provinsi di Kota Kendari yang telah dihitung dengan mertode RII kemu dian dilakukan perbandingan dengan kondisi eksisting yang ada dengan metode uji perbandingan Annova (Uji F) dengan bantuan software Microsoft Excel, yang diuraikan dalam Tabel 11:

Dari hasil analisis uji beda dengan $\mathrm{T}$ Test tersebut kemudian output yang dihasilkan ditampilkan dalam Tabel 12 berikut:

Tabel 12. Paired Samples Test

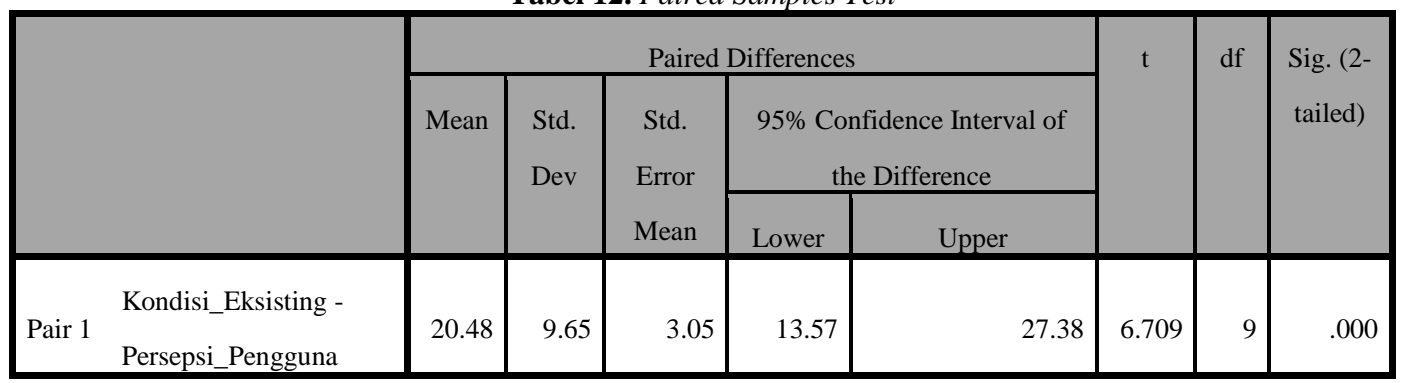

Statistik uji yang dapat dilihat dari hasil ouput yang ditampilkan dalam tabel diatas adalah sebagai berikut:

$$
\begin{aligned}
& \text { Sig. }=0,00<\alpha=0.05 \text { dan } \\
& \mathrm{T}_{\text {hitung }}=6,709 \geq \mathrm{T}_{\text {Tabel }}=3,169
\end{aligned}
$$

Sehingga dari hasil perhitungan signifikansi dan $\mathrm{T}_{\text {hitung, }}$ diketahui bahwa Sig. $<\alpha=$ dan $\mathrm{T}_{\text {hitung }} \geq \mathrm{T}_{\text {Tabel }}$ sehingga kesimpulan yang ditarik adalah Menolak $\mathbf{H}_{0}$ atau dengan kata lain kondisi jalan menurut persepsi pengguna jalan secara signifikan berbeda dengan kondisi jalan provinsi yang telah ada di Kota Kendari.

Dari hasil pengujian tersebut dapat kita lihat bahwa tingkat layanan yang diterima oleh pengguna jalan belum dapat memenuhi ketentuan Standar Pelayanan Minimal bidang jalan dimana menurut pendapat pengguna jalan, masih terdapat jalan provinsi yang berlubang yang mengganggu perjalanan pengguna jalan dari segi kenyamanan dan keselamatan saat melawati ruas jalan tersebut. Lebar badan jalan juga menjadi perhatian pengguna jalan yang menyatakan bahwa lebar jalan provinsi yang ada cenderung kurang memadai serta sistem drainase yang tidak berfungsi yang menyebabkan tergenangnya air hujan ke badan jalan.

\section{Konektivitas}

Berdasarkan perhitungan tingkat konektifitas di atas, dapat diketahui bahwa jalan provinsi yang dibutuhkan untuk menghubungkan seluruh pusat produksi dan pusat kegiatan di Kota Kendari belum dapat memenuhi standar pencapaian pelayanan minimal dimana konektivitas 
wilayah yang dihubungkan oleh jalan provinsi di Kota Kendari hingga tahun 2017 baru mencapai angka 89,40\%.

Sedangkan berdasarkan rata-rata nilai RII yang dihitung pada pengguna jalan, nilai konektivitas jalan provinsi yang ada di Kota Kendari adalah sebesar 81,2\%. Yang mana, dalam perhitungan ini menunjukkan tingkat kondisi akses penghubung antara masing-masing ruas jalan provinsi yang ada dengan pusat kegiatan yang ada di Kota Kendari.

Namun dalam hal keterhubungan antara pusat produksi dan pusat kegiatan telah dapat memenuhi standar pelayanan menurut persepsi masyarakat. Tabel 11 menunjukkan pemetaan keterhubungan antara pusat produksi dan pusat kegiatan dengan ruas jalan provinsi menurut persepsi pengguna jalan.

Tabel 11. Tingkat Konektivitas menurut Pengguna Jalan

\begin{tabular}{|c|c|c|c|c|c|c|c|c|c|}
\hline KONEKTIVITAS & $\begin{array}{l}\text { JL. H. } \\
\text { LA } \\
\text { MUSE }\end{array}$ & $\begin{array}{l}\text { JL. } \\
\text { ORINUNGGU }\end{array}$ & $\begin{array}{c}\text { JL. P. } \\
\text { ANTASARI }\end{array}$ & $\begin{array}{l}\text { JL. DEWI } \\
\text { SARTIKA }\end{array}$ & $\begin{array}{c}\text { JL. } \\
\text { BRIGJEN } \\
\text { KATAMSO }\end{array}$ & $\begin{array}{l}\text { JL. } \\
\text { SUDIRMAN }\end{array}$ & $\begin{array}{c}\text { JL. RA } \\
\text { KARTINI }\end{array}$ & $\begin{array}{c}\text { JL. } \\
\text { MARTA } \\
\text { DINATA }\end{array}$ & $\begin{array}{c}\text { BATAS } \\
\text { KOTA - } \\
\text { JL. } \\
\text { SUTOMO }\end{array}$ \\
\hline $\begin{array}{l}\text { Pusat } \\
\text { Pemerintahan Kota } \\
\text { Kendari }\end{array}$ & $75 \%$ & $88.00 \%$ & $77.20 \%$ & $63.00 \%$ & $80.40 \%$ & $65.20 \%$ & $67.00 \%$ & $67.00 \%$ & $81.00 \%$ \\
\hline $\begin{array}{l}\text { Kawasan Strategis } \\
\text { Teluk Kendari }\end{array}$ & $70 \%$ & $92.40 \%$ & $80.40 \%$ & $67.40 \%$ & $85.90 \%$ & $70.70 \%$ & $65.90 \%$ & $75.00 \%$ & $71.40 \%$ \\
\hline RSUD Abu Nawas & $89 \%$ & $95.70 \%$ & $87.00 \%$ & $77.20 \%$ & $87.00 \%$ & $92.40 \%$ & $84.10 \%$ & $88.60 \%$ & $79.80 \%$ \\
\hline RSUD Bahteramas & $92.40 \%$ & $90.20 \%$ & $83.70 \%$ & $77.20 \%$ & $89.10 \%$ & $89.10 \%$ & $84.10 \%$ & $85.20 \%$ & $88.10 \%$ \\
\hline $\begin{array}{l}\text { Pelabuhan } \\
\text { Perikanan } \\
\text { Samudera }\end{array}$ & 82.6 & $72.80 \%$ & $72.80 \%$ & $67.40 \%$ & $78.30 \%$ & $89.10 \%$ & $79.50 \%$ & $84.10 \%$ & $79.80 \%$ \\
\hline $\begin{array}{l}\text { Pelabuhan } \\
\text { Nusantara }\end{array}$ & $70 \%$ & $92.40 \%$ & $80.40 \%$ & $67.40 \%$ & $85.90 \%$ & $70.70 \%$ & $65.90 \%$ & $75.00 \%$ & $71.40 \%$ \\
\hline $\begin{array}{l}\text { Terminal Type A } \\
\text { Puuwatu }\end{array}$ & $82.60 \%$ & $94.60 \%$ & $83.70 \%$ & $73.90 \%$ & $75.00 \%$ & $89.10 \%$ & $75.00 \%$ & $85.20 \%$ & $82.10 \%$ \\
\hline $\begin{array}{l}\text { Terminal Type A } \\
\text { Baruga }\end{array}$ & $95 \%$ & $91.30 \%$ & $76.10 \%$ & $78.30 \%$ & $90.20 \%$ & $75.00 \%$ & $69.30 \%$ & $81.80 \%$ & $88.10 \%$ \\
\hline $\begin{array}{l}\text { Universitas } \\
\text { Haluoleo Kendari }\end{array}$ & $79.30 \%$ & $87.00 \%$ & $81.50 \%$ & $78.30 \%$ & $68.50 \%$ & $76.10 \%$ & $75.00 \%$ & $86.40 \%$ & $84.50 \%$ \\
\hline $\begin{array}{l}\text { Pusat } \\
\text { Pemerintahan } \\
\text { Provinsi Sulawesi } \\
\text { Tenggara } \\
\end{array}$ & $92.40 \%$ & $95.70 \%$ & $84.80 \%$ & $80.40 \%$ & $93.50 \%$ & $92.40 \%$ & $75.00 \%$ & $92.00 \%$ & $85.70 \%$ \\
\hline $\begin{array}{l}\text { Pusat Bisnis dan } \\
\text { Perdagangan Kota } \\
\text { Lama }\end{array}$ & $68.48 \%$ & $91.30 \%$ & $76.10 \%$ & $66.30 \%$ & $71.70 \%$ & $60.90 \%$ & $72.70 \%$ & $73.90 \%$ & $86.90 \%$ \\
\hline Pasar Kota & $58.70 \%$ & $94.60 \%$ & $80.40 \%$ & $72.80 \%$ & $75.00 \%$ & $71.70 \%$ & $79.50 \%$ & $79.50 \%$ & $83.30 \%$ \\
\hline Pasar Baru & $75 \%$ & $83.70 \%$ & $75.00 \%$ & $73.90 \%$ & $78.30 \%$ & $83.70 \%$ & $76.10 \%$ & $81.80 \%$ & $83.30 \%$ \\
\hline Pasar Baruga & $98 \%$ & $96.70 \%$ & $84.80 \%$ & $73.90 \%$ & $95.70 \%$ & $92.40 \%$ & $83.00 \%$ & $92.00 \%$ & $86.90 \%$ \\
\hline $\begin{array}{l}\text { Lippo Plaza } \\
\text { Kendari }\end{array}$ & $88 \%$ & $92.40 \%$ & $81.50 \%$ & $77.20 \%$ & $93.50 \%$ & $92.40 \%$ & $80.70 \%$ & $92.00 \%$ & $79.80 \%$ \\
\hline Mall Mandonga & $87 \%$ & $92.40 \%$ & $84.80 \%$ & $77.20 \%$ & $78.30 \%$ & $92.40 \%$ & $80.70 \%$ & $92.00 \%$ & $81.00 \%$ \\
\hline $\begin{array}{l}\text { Briliyan Plaza } \\
\text { Kendari } \\
\end{array}$ & $73.90 \%$ & $95.70 \%$ & $82.60 \%$ & $77.20 \%$ & $81.50 \%$ & $92.40 \%$ & $79.50 \%$ & $92.00 \%$ & $83.30 \%$ \\
\hline
\end{tabular}

Keterangan:

Akses Jalan dalam Kondisi Baik

Akses Jalan Diaspal Baik namun Masih Berlubang

\section{- Kendala Pelaksanaan SPM}

Berdasarkan wawancara yang dilakukan pada tenaga ahli Dinas SDA dan BM Prov. Sultra, beberapa kendala yang dihadapi sebagai penyelenggara jalan provinsi diKota Kendari dalam penerapan SPM:

1) Terabatasnya anggaran yang dimiliki oleh pemerintah untuk pelaksanaan kegiatan penanganan jalan seperti pemeliharaan dan pembangunan jalan. Hal ini kemudian disiasati dengan program prioritas untuk penanganan jalan [9].

2) Kurangnya sumber daya baik manusia maupun anggaran daerah untuk dapat melaksanakan survey manual setiap tahun sehingga data kondisi jalan tidak selalu tersedia dengan valid untuk setiap tahunnya. Untuk melakukan survey kondisi jalan biasanya dengan menunggu anggaran untuk kegiatan survey yang bekerja sama dengan Kementerian PU misalnya penggunaan Dana Alokasi Khusus atau Dana Dekonsentrasi dan Tugas Pembantuan [10].

3) Kurangnya penyedia jasa yang kompeten dalam pengerjaan kegiatan penanganan jalan sehingga dapat menyebabkan kerusakan jalan yang tidak sesuai dengan umur rencana. Hal ini kemudian ditangani dengan melakukan tahap seleksi yang ketat dalam penerimaan calon penyedia jasa serta upaya pembinaan perusahaan jasa konstruksi melalui penerapan kualifikasi/klasifikasi persyaratan kemampuan dalam pendirian badan usahajasa konstruksi [11]. 


\section{KESIMPULAN}

Berdasarkan hasil penelitian yang dilakukan baik survey langsung maupun terhadap pengguna jalan, dapat disimpulkan bahwa:

1. Tingkat kondisi jalan provinsi di Kota Kendari untuk tahun 2017 baru mencapai angka 55,60\% sedangkan tingkat konektivitas jalan yang menghubungkan jalan provinsi dengan pusat produksi dan pusat kegiatan di Kota Kendari baru mencapai angka 89,40 \%.

2. Hasil evaluasi terhadap capaian nilai Standar Pelayanan Minimal kondisi jalan sesuai dengan Permen PU No. 1 Tahun 2014 dapat dikatakan belum memenuhi dari total $60 \%$ tingkat capaian Standar Pelayanan Minimal yang harus dicapai hingga akhir tahun 2019. Hal ini sejalan dengan tingkat layanan yang diterima oleh masyarakat sesuai dengan persepsi pengguna jalan yang baru mencapai kisaran 49,25\%. Namun diharapkan gap sebesar $4,4 \%$ dapat dipenuhi hingga akhir tahun capaian dengan adanya kegiatan pemeliharaan dan peningkatan jalan.

Nilai konektivitas jalan juga belum memenuhi dari total $\mathbf{1 0 0 \%}$ capaian Standar Pelayanan Minimal. Namun $\mathbf{8 1 , 2 \%}$ responden pengguna jalan menyatakan akses jalan yang menghubungkan jalan provinsi dengan pusat produksi dan pusat kegiatan di Kota Kendari dalam kondisi baik dan sisanya sebesar $\mathbf{1 8 , 8 \%}$ menyatakan akses telah diaspal namun masih berlubang.

3. Kendala penerapan Standar Pelayanan Minimal pada ruas jalan provinsi di Kota Kendari adalah terbatasnya anggaran untuk kegiatan pembangunan maupun pemeliharaan jalan, kurangnya sumber daya manusia dan anggaran daerah untuk dapat melaksanakan survey kondisi jalan, serta kurangnya penyedia jasa lokal yang kompeten untuk melaksanakan kegitan penanganan jalan.

\section{DAFTAR PUSTAKA}

[1] Permen PU 1/14.Peraturan Menteri Pekerjaan Umum No. 1/Prt/M/2014 Tentang Standar Pelayanan Minimal Bidang Pekerjaan Umum Dan Penataan Ruang.Jakarta.
[2] Iskandar, H. (2011) "Kajian Standar Pelayanan Minimal Jalan Untuk Jalan Non-Tol (Minimal Service Standar Analysis for Non Toll Roads)" Pusat Litbang Jalan dan Jembatan.Jakarta. www.pu.go.id

[3] Sukirman, S. (1999), Perkerasan Lentur Jalan Raya, Nova, Bandung.

[4] Arikunto, S. (2013) Prosedur Penelitian Suatu Pendekatan Praktek. Cet - 15. Rineka Cipta. Jakarta

[5] Badan Penelitian dan Pengembangan Kementerian Pekerjaan Umum dan Perumahan Rakyat, (2016), Laporan Akhir Konektivitas Jalan Mendukung Sistem Logistik Nasional, Sidoarjo.

[6] Arikunto, S. (2013a).Manajemen Penelitian. Cet 12, Rineka Cipta. Jakarta.

[7] Ratnasari, V. (2016).Pengambilan Keputusan.Materi Kuliah. Jurusan Teknik Sipil ITS.Surabaya.

[8] Perdakot 1/12.Peraturan Daerah Kota Kendari No. 1 Tahun 2012 tentang Rencana Tata Ruang Wilayah Kota Kendari Tahun 2010 - 2030. Kendari.

[9] Perdaprov 2/14.Peraturan Daerah Provinsi Sulawesi Tenggara No. 2 Tahun 2014 tentang Rencana Tata Ruang Wilayah Provinsi Sulawesi Tenggara 2014-2034. Kendari

[10] Iskandar, T.M. (2015), Kajian SPM Konektivitas dan Kondisi Jalan di Kota Banda Aceh, The $18^{\text {th }}$ FSTPT Inernational Symposium, UNILA, Bandar Lampung August 28 2015. Bandar Lampung

[11] Syukriy, A. (2016) Analisis Varian Anggaran Pemerintah Daerah Penjelasan Empiris dari Perspektif Keagenan. Syukriy.wordpress.com (23/11/2017)

[12] Hutauruk, A.G. (2013), “Analisis Prediksi Prediksi Kondisi Perkerasan Jalan Menggunakan Pendekatan HDM-4 Untuk Penanganan Jalan (Studi Kasus Ruas Jalan Nasional BTS. Kota Gresik-Sadang)", Tesis, Institut Teknologi Sepuluh Nopember, Surabaya 